\title{
FACE POLITENESS OF MAKASSAR PEOPLE
}

\author{
Nur Qalbis \\ Universitas Negeri Jakarta \\ nur.qalbis@gmail.com
}

\begin{abstract}
This research explains faculty aspects among Makassar tribe community in South Sulawesi. The objective is to provide an understanding of Makassar facilitation aspect in Gowa district. This study describes the form of expressions related to the concept of face (self-esteem, image) that is loss of face, face thickness, and face search of speech acts in the community. Face has two aspects: positive face and negative face. This research uses qualitative approach, methods with observation, interview, and recording techniques. The results of this study indicate that there is a shift in the concept of Makassar society face that this is influenced by the level of social, education, and gender. Social status here is no longer influential in preserving the concept of the face. This is because there is a shift between the social statue bangsawa no longer care about it, let alone the young. Furthermore, the level of education, that the higher the education then they will maintain the concept of face in interacting with each other in the community. Finally, sex also determines facial or facial salvation in communicating, compared with male women are very maintaining the concept of advance in communicating and interacting in the community.
\end{abstract}

Keywords: face politeness, Makassar tribe, qualitative approach,

The phenomenon of language among the younger generation who abandon the values of politeness in the face of language amid the shift of values in the global society as the reason the author tries to promote the theme of politeness advance so that young people can understand and continue in society. Language politeness can be viewed as an attempt to avoid conflicts between speakers and speech partners. In this case, courtesy is the result of the implementation of social rules and the selection of communication strategies. Persuasion in the face of language is important wherever a person is. Every member of society believes that the politeness of the face that is applied reflects the culture of a society. Moreover, every society there is always a social hierarchy imposed on groups of their members. This happens because they have determined certain judgments, for example between teacher and student, parent and young generation, leader and led, and others. In addition, the context factor also causes the politeness of the face to be applied.

Language and ethics or courtesy are closely related, whereby whoever we are and whatever our profession, it is certainly not possible to escape the use of language. The term ethics itself (ethikos: Greece) means ethical or ethos attitudes. This term was already used by Aristotle in the 5th century $\mathrm{BC}$ to assess human nature, character, or character. If then moral is also made an integral part in ethical talks, this term only later raised by Cicero. Furthermore Wardhaugh argues that language politeness is a language behavior that takes into account solidarity, power, intimacy, relationship status among participants, and rewards. Language politeness is also determined by awareness of social habits.

The values contained in the life of the Bugis-Makassar people, especially the younger generation who in their daily life use language that is far from the rules of cultural values of eastern. So it is feared people will use many words freely without being based on moral and religious considerations. As a result there will be conflicts and disputes in the community because of the use of language that is not polite in communicating. This creates an unfavorable situation in the family, school, and community environment. 
Makassar society culture that often conflict or brawl between citizens due to the character of Makassar society is hard and hot. This is triggered also by the location of Makassar's infertile tribal region and has become their character. Where the philosophy of their lives that we used to hear as the expression sira na pacce is the principle of life for the tribe of Makassar. Sirik is used to defend the honor of those who want to rape his pride, while pacce is used to help fellow members of society who are in suffering. If sirikna pacce as a view of life does not have a person, will be able to result in the person behave beyond the behavior of animals because it has no elements social concern, and just want to win alone.

One proof of the phenomenon that the culture in Indonesia began to extinct even, half extinct raised by the Director General of Culture RI Hilmar Farid states from year to year custom culture in Indonesia increasingly declined. "Current conditions exist that still maintain the culture, there are intact, there are half, some are extinct," said Hilmar, quoted from the East Tribune online states. "Makassar and all regions in South Sulawesi still maintain its cultural integrity, it indicates that society and government appreciate its own culture," he said.

Lately the phenomenon of community life in South Sulawesi tends to no longer show the feature as a continuity of Bugis-Makassar cultural values. Ishak Ngelyaratan considers that the main values of Bugis-Makassarese culture are no longer "grounded", no longer have the vitality in the life of the people of South Sulawesi today. Furthermore Mattulada states that the order of norms derived from pangadereng (ade 'rapang, talk, wari' and sara ') has been slowly collapsed, the values and norms system that is ingrained by ingenious clever pasts from generation to generation increasingly displaced. The growing development of technology and information that is nowadays also creates a number of changes to the direction of community orientation in various aspects of his life. Changes in the orientation of values in the life of the people of South Sulawesi today that base the moralisticreligious values toward values that give high appreciation to the value of power and pragmatic economic value, not based on the values derived from cultural experiences that have been passed down from generation to generation, give birth to actions justifies any means to achieve the goal.

The Bugis-Makassar tribe is the more dominant tribe in South Sulawesi. Bugis-Makassar tribe majority business-oriented or traders Suku is also religious. Bugis-Makassar tribe is a tribe that strongly upholds dignity and dignity and greatly avoids actions that result in the decline of self-esteem or dignity of a person. In Makassar tribe people who live in Gowa they still hold the philosophy of life siri 'na pacceserta is a life view that need to be preserved for the younger generation today because it is starting to erode by the development of the times and the influence of technology from outside.

According to Mattulada there are three notions of the concept of siri 'that is: first is shame, second is the driving force to destroy the ready ones who have offended one's honor, and the third is the driving force to work or strive as much as possible (Mattulada 1995: 62). So sisri na pacce is a concept in Makassar culture that can not be separated in the life order of Makassar tribe society.

\section{Linguistic politeness}

Various views on linguistic politeness have evolved. One of them is Spolsky, he views linguistic politeness as a speaker's language expression that recognizes and respects rights and feelings in the social interactions of other participants. Another view by Rash suggests that linguistic politeness is an important aspect of human communication. People can live together peacefully and harmoniously if they adhere to certain rules of politeness and convention when communicating with each other through all the layers they live in their community. The significance of politeness in social interaction is also put forward by Eelen and Watts, who in principle see linguistic politeness as related to avoid conflict strategies as well as strategies for establishing or maintaining good relationships between or among participants involved. In other words, linguistic politeness is the way people choose to speak taking into account the feelings of others. It can also be defined as a kind of strategy or technique 
used by people in a particular speech community to avoid conflict or friction when they communicate with each other.

An interesting look at linguistic politeness is presented by Hill, et al. They claim that politeness can be drawn into two poles, ie, politeness as 'discernment' and politeness as 'volition'. Persecution as an affirmation is manifested through submission or in accordance with social norms and cultural values. In the concept of politeness, a person is judged as polite if his communicative behavior embraces social norms and / or cultural values exercised by the community in which they are in it.

Another view of linguistic politeness has been presented by Watts. In this view, politeness is a kind of 'political behavior' defined as a behavior that is limited by socio-cultural norms aimed at achieving and / or maintaining a balance in the personal relationships between individuals in society in the interaction process. in view of this politeness is political behavior with clear markers and can be interpreted conventionally to achieve social and communicative targets of interaction between individuals or members of society using the natural form of speech in the discourse that suits the purpose of the interaction.

Linguistic politeness has also been studied from a sociolinguistic standpoint by sociologist Erving Goffman in which the concept of 'face' is made in the analysis of polite behavior in social interaction. Hartung, looking at politeness from a sociolinguistic point of view, he states that since the time of the theory of linguistic politeness was first developed, especially by Brown \& Levinson, most sociolinguistic studies on politeness have been associated with the concept of the face.

As Setlock has pointed out, theory-based politeness advance will collapse when it is on intercultural communication as the concept of the face differs from one culture to another. A serious question about the concept of advance will be used as a reference point in intercultural interaction? Similarly, if politeness refers to the observance of social-cultural norms in which socio-cultural norms should be observed? As the concept of advance varies in different communities and cultures and socio-cultural norms also vary from society to society, politeness in intercultural communication seems to require specific analysis.

\section{Advance Concepts}

The concept of the face is told by Goffman to peel about 'face work', he interprets the face as a positive social value demanded by a person in interaction. Advance means an image that represents the social acceptance shown to others as a kind and commendable action. Furthermore Goffman explains about the division of a person's duty to save / keep face, which is keeping his own face and keep the face of others / partners said. In the process of rescuing the Goffman's face focuses on the embarrassment that is borne by someone when in an unacceptable environment. In doing so, it provides a means of restoring the shame by being responsible for what has been done or apologized for correcting its mistakes.

The most influential theory of politeness put forward by Brown and Levinson. Brown and Levinson's philanthropy theory is a facial concept as suggested by Goffman. The term face in art of reputation or reputation was first used in English in 1876 as a translation of the Chinese term dill Tian in the phrase 'The arrangement which in Chinese culture means loss of face. Since then it has been used extensively in phrases such as loss of face, and saves face, as in the following example from Galsworthy.

For example:

They've got to save face. Saving face is the strongest motive in the world. (They must keep face.

Keeping face is the basic motive in the world).

Goffman (1967) defines the face as follows:

.......one's positive social values effectively and appoint itself to another line assumes he or she has been taken during a particular contact. Face is a self-image depicted in terms of social attributes, 
although images can be shared, such as when a person does something good like his profession or his religion by showing good behavior for himself.

In politeness, the theory of the face is something that is well understood by the feelings of each individual as self-esteem or self-image. This imagery can be corrupted, defended or enhanced through interaction with others. Face has two aspects - positive face and negative face. Positive faces are reflected in the desire to be liked, approved, respected and valued by others, while the negative face is reflected in the desire to not be hampered or burdened, to have the freedom to act as freedom to do something that he likes.

So the face is something that is invested, and it can be lost, maintained or enhanced, and must constantly take place in interaction. In general, people work together (and consider cooperation with each other) in maintaining mutual vulnerability of the face. in the interaction, such cooperation is based on a face full of criticism. Usually the face of everyone depends on the other person being nurtured, and because people can be expected to keep them facing if threatened, and in, defending themselves to threaten others, it is in general the best interests of each participant to keep each other's face, acting with a way that ensures other participants whose agents are cautious of the assumptions about the face. Furthermore, the content of the face will differ in different cultures (what are the definite boundaries for the private domain, and what is the relevant public content personality composed in), we assume that the members' mutual self-image or face, self to it in interaction, is universal.

It will be possible to treat respect for the face as the norms or values by community members. Instead we treat the facial aspect as a basic desire, which each member knows every other member's wishes, and which in general is the interest of each member to partially satisfy. In other words, we take the Wiberian facet of a more rational zweckrational model of individual action, because the wertrational model (which will treat the face as a value or norm is questionable) fails to account for the fact that confronting this is not a firm right.

In the social interaction that participants who engage in interaction do not live in a context that has created a hard social relationship. In their daily-hearted social interactions, people usually behave as if their hopes regarding the good name of their own society or their facial desires will be respected. If the speaker expresses something that poses a threat to the expectations of another individual with respect to his or her own good name, this statement is described as a facial threat (FTA) action, another possibility, given the likelihood that some of the action will be described as a threat to the face of the person another, the speaker can say something to reduce the likelihood of the threat. This action is called a face-saving action.

\section{METHODS}

This research is a qualitative research with ethnographic method of communication based on Hymes theory developed by Saville-Troike with pragmatic approach. Qualitative research is a method used to examine the condition of natural objects, where researchers are as a key instrument, data collection techniques are done in triangulation, data analysis is inductive / qualitative, and the results of research more emphasis on the meaning than generalization. This research was conducted with the intention of collecting data, processing data, analyzing data, and presenting data objectively about the politeness of the face of Makassar tribe who is domiciled in Gowa.

\section{RESULT AND DISCUSSION}

From the data in the can, then selected according to the data needed, namely the speech that has elements related to the politeness of the faces of Makassar tribe community. The data were then analyzed using the ethnographic method of communication based on Hymesspeaking concept. 
One of the most influential areas in the growth and development of South Sulawesi region from the past until now is the Gowa level II area. In the past this area was known as the center of the kingdom of Makassar people who once controlled not only most of Sulawesi's mainland, but even sent fleets to attack Malacca. Now Gowa has evolved into a settlement that is still inhabited by the majority of the population of Makassar tribe, with a unique cultural background and different from other tribes.

Courtesy is expressed in attitude and language speech. Passing in front of the sitting person should be avoided, even if forced to pass, then it should be by bowing the body swinging right hand forward while saying 'tabek' or 'tabek lompo', "excuse". When eating, for a man must wear head cover (songkok) or passapu. When the arrival of guests, must be received with neat clothes, if while sitting, then stand up then sit with guests. To go into people's homes, first have to sign, that there are people outside, but not directly into the house.

The politeness of Gowa society face based on the observation that Makassar culture contains the noble value of universal, but less actualized consciously and lived in everyday life. The core essence of Makassar culture is actually a form of conception of 'tau' (human), that is, human being in this context, in social interaction is highly regarded its existence. This concept underlies the view of Makassaran people's life that gave rise to the appreciation of their fellow human beings. This form is manifested in the "sipakatau" attitude which means to understand and appreciate each other.

The cultural attitudes of sipakatau in the life of Makassar people are translated into the conception of sira na pacce. By upholding the principle of sira na pace. It is only within the circle of those who live and are able to live the way of life sipakatau that can openly accept each other kinship and kinship relationship.

The data below shows the politeness between the speaker and the speech partner

Pn : What injo Ingga nak ....? (what do you carry?) (given rambutan)

$\mathrm{Mt} \quad$ : anne patta (this is patta) (given rambutan)

Pn : oh tarima love (thank you) .... sumpaeng irawa niaki smell Malik, najanjika rambutan (I

met Andi Malik ago and promised rambutan)......

Mt : oh iye (oh iya)

The use of forms of politeness between speakers and spouses who have close kinship relationships indicates intimacy and harmonious relationship between the two. Use of naughty greeting to kemanakan as a sign of uncle's affection on mt (kemanakan). Also patta greeting, the smell is a tribute to someone because of his noble title in the bugis-makassar tribe. Furthermore the use of iye is a form of politeness which means yes that is very polite compared with yes or iyo. The concept of appropriate frontal courtesy that exists on Brown and Levinson's theories that both speakers and their spouses both keep each other's faces positive or saves their faces with speech in interacting / communicating between the two.

In addition, the use of the above greetings appear very smooth and polite between the uncle's words to kemanakan, said uncle to kemanakan submitted smoothly so as not to threaten the face or benefit the uncle's face. The form of the above is relaxed but still using the rules of cultural politeness of Makassar.

The use of non verbal civility for tribal society in interacting with their community is very concerned about the use of appropriate title or greeting, that is with whom they speak. The use of non verbal civility for ordinary people when meeting with people who are older or who have high social strata, they usually shake hands with kissed hands have a higher status. Why are they very polite to people with higher social status because they generally have kubedudukan or jabata in government and are considered as community leaders.

This is in line with Goffman's opinion developed by Brown and Levinson which means caring attitude and attitude to the face or face for speakers and partners. Face or face does not mean physical form but self-esteem or self image (public image). In Makassar culture the concept of advance is 
closely related to the siri 'na pacce' culture which means self-esteem and solidarity. So the utmost courtesy is the ability to maintain feelings, self-esteem and others.

Adik: bangunmeki daeng

Kakak : iye ....... iye

Adik:bangunmeki jam berapami ini, terlambatmeki, cepatmaki. Bangunmaki cepatki pergi mandi

Ibu : bangunmi kakak ta?

Kakak : ayomi....

Furthermore, the above speech is a speech between brother and sister, this looks familiar and relaxed when when younger brother with imperative speech asked brother to take to school, also involved mother in conversation above. The use of honorific forms of politeness like the word iye, particles -ki, our pronouns above influential in the daily culture of Makassar society. The concept of sipakatau is a concept that views human beings as human beings. It means mutual respect as a fellow human being. Respect for fellow human beings and mutual respect for each member of the community. The above tutorial uses honorific courtesy in the act of requesting sister to kakkak to deliver her to school. Request sister delivered in a relaxed way because of social status younger brother as a younger brother. The request is by using forms of linguistic politeness oriented to social solidarity. Such as waking up, rapidly maki, kakak ta, where the relationship of speakers and partners said seem parallel in kinship. Also the use of iye as pemarkah politeness which is a form of honorific politeness in Makassar society.

\section{CONCLUSION}

Makassar people who live in Gowa use Makassar and Indonesian language in communicating in family and society. The forms of speech used are spoken by the speakers to the partners in various ways. The incorrect form of speech that the speaker speaks to a spokesperson will cause a face threat or even damage the speaker's face. A casual, informal or informal tuft or formal-looking speech may threaten the speaker's face.

Thus, the use of a polite word is done by a familiar speaker on the contrary, speakers with farreaching relationships will use modesty. So politeness in relation to the concept of face / face management (face management) refers to Goffman's view of the wishes of people. Everyone has two faces: positive face and negative face. Positive face is the desire of people to all his actions appreciated by others, while the negative face of each person's desire that all his actions are not obstructed by others. So the politeness of the face in the interaction between speakers and partners said must always be maintained in the sense of maintaining self-esteem or image. So situations such as loss of face in interaction within society are always maintained on each individual.

\section{REFERENCES}

Brown, P. dan Stephen C. Levinson. . Politeness: Some Universals in Language Usage. (Cambridge: Cambridge University Press, 1978.

Emzir, Metodologi Penelitian Kualitatif: Analisis data. Jakarta. Raja Grafindo Persada. 2010

Fraser, Bruce. Perpekstive of politeness. Dalam Journal of pragmatics, Vol.14:219-236. 1990.(diakses 5 oktober 2015).

Hamid, Abu, dkk., Siri' \& Pesse': Harga Diri Manusia Bugis Makassar, Mandar, Toraja. Makassar: Pustaka refleksi. 2009.

H.P. Achmad, “Wacana Pengajaran Bahasa”. Pengukuhan Guru Besar Bidang Ilmu Pengajaran Bahasa, (Jakarta: FPBSUNJ, 2006). 
Hymes, Dell. Ethnnography. Linguistics, Narrative Inequality: Toward an Understanding of Voice (London: Taylor and Francis, 1996).

Jenny Thomas, Meaning in Interaction, New York:Pearson Education Ltd, 1995.

Kramsch, Claire. Language and Culture. (Oxford: Oxford University Press, 1988.

Masnur, Musclich, Kesantunan Berbahasa Indonesia Sebagai Pembentuk KepribadianBangsa, http://researchengines.com.1006 masnur 2.html (diakses 3 Oktober 2015).

Rahardi, Kunjana. Pragmatik: Kesantunan Imperatif Bahasa Indonesia. (Jakarta : Penerbit Erlangga. 2005).

R.J.Watts. Politeness.( Cambridge: Cambridge University Press.2005).

Ronald Wardaugh, An Introduction to SociolinguisticsOxford: Blackwell Publishing, 2006.

Sugiyono. Metode Penelitian Kuantitatif, Kualitatif, dan R\&D. Bandung: Alfabeta, 2014.

Wahyu Wibowo, Konsep Tindak Tutur Komunikasi .Jakarta: PT Bumi Aksara, 2015

Yatim, Nurdin., Subsistem Honorifik Bahasa Makassar: Sebuah Analisis Sosiolinguistik. (Jakarta: Departemen Pendidikan dan Kebudayaan, Direktorat Jenderal Pendidikan Tinggi, Direktorat Pembinaan Penelitian dan Pengabdian pada Masyarakat. 1983. 